\title{
PAIRED DATING OF PITH AND OUTER EDGE (TERMINUS) SAMPLES FROM PRE- HISPANIC CARIBBEAN WOODEN SCULPTURES
}

\author{
Fiona Brock ${ }^{1,2}$ • Joanna Ostapkowicz ${ }^{3}$ Christopher Bronk Ramsey ${ }^{1}$ - Alex Wiedenhoeft ${ }^{4} \cdot$ \\ Caroline Cartwright ${ }^{5}$
}

\begin{abstract}
Radiocarbon dating of historical and archaeological wood can be complicated, sometimes involving issues of "inbuilt" age in slow-growing woods, and/or the possibility of reuse or long delays between felling and use of the wood. Terminus dates can be provided by dating the sapwood, or the outermost edge of heartwood, while a date from the pith can give an indication of the first years of growth. A sequence of samples from specific points within the bole can be used to determine the growth rate of the tree. Such a combined dating strategy is particularly useful in cross-referencing dates from a single piece, better placing it in its chronological context. This paper reports paired or multiple dates from 11 wooden sculptures dated as part of the Pre-Hispanic Caribbean Sculptural Arts in Wood project, which studied 66 wooden artifacts attributed to the pre-colonial Taíno, the indigenous peoples of the Caribbean's Greater Antilles. The calibrated ages of the pieces published here range from $\sim A D$ 700-1500, indicating that the Taino were producing elaborate sculptures much earlier than previously thought. The paired or multiple dates from these carvings confirmed the accuracy of the results, and were also used to construct a growth rate model of what was expected to be a slow-growing species (Guaiacum sp.). This model demonstrates that the boles used to create the sculptures grew on average $1 \mathrm{~cm}$ every $6-13 \mathrm{yr}$.
\end{abstract}

\section{INTRODUCTION}

The Taíno inhabited Hispaniola (Haiti and the Dominican Republic), Puerto Rico, Jamaica, Cuba, the Bahamas, and the Turks and Caicos Islands at the time of first European contact in the late 15th century. Culturally complex and diverse, they spoke different languages and varied in artistic expression, but were linked broadly across this chain of islands through a shared ancestry and deep, far-reaching webs of social connection (Wilson 2007; Oliver 2009). Their ancestors had arrived from mainland South America via the Lesser Antilles, settling in Puerto Rico and Hispaniola by $\sim \mathrm{AD} 400$, and interacting with the local inhabitants who had occupied the Greater Antilles for millennia (Wilson 2007). Populations flourished and expanded into Cuba, Jamaica, and the Bahamas by $\sim$ AD 600 (Wilson 2007). From about this period, complex, stratified societies began to emerge (Oliver 2009:25), inspiring, among other things, an artistic florescence.

The Taíno created visually striking wood sculptures made of single boles and decorated with inlays of guanin (a gold-copper alloy) or shell: there are no extant examples featuring multiple wood components. By the time of Columbus' arrival in 1492, wooden sculpture is documented as being central to Taíno religious and social practices (Colón 1992:151; de Oviedo y Valdés 1959:I:112; Pané in Arrom 1999:25). The carvings took a wide variety of forms including cohoba stands used to hold hallucinogenic snuffs during ceremonies (e.g. Figure 1a); cemis that depicted spirits, deities, and ancestors; reliquaries (e.g. Figure 1b); and duhos (seats used by chiefs and other dignitaries during rituals and important sociopolitical occasions, e.g. Figure 1c).

\footnotetext{
${ }^{1}$ Oxford Radiocarbon Accelerator Unit, Research Laboratory for Archaeology \& the History of Art, University of Oxford, Dyson Perrins Building, South Parks Road, Oxford OX1 3QY, United Kingdom.

${ }^{2}$ Corresponding author. Email: Fiona.brock@rlaha.ox.ac.uk.

${ }^{3}$ World Museum Liverpool, William Brown Street, Liverpool L3 8EN, United Kingdom.

${ }^{4}$ Center for Wood Anatomy Research, Forest Products Laboratory, USDA Forest Services, One Gifford Pinchot Drive, Madison, Wisconsin 53726-2398, USA.

${ }^{5}$ Scientific Research Laboratory, British Museum, London WC1B 3DG, United Kingdom.
}

(C) 2012 by the Arizona Board of Regents on behalf of the University of Arizona Proceedings of the 6th International Radiocarbon and Archaeology Symposium, edited by E Boaretto and N R Rebollo Franco RADIOCARBON, $\mathrm{Vol}$ 54, $\mathrm{Nr} 3-4,2012, \mathrm{p}$ 677-688 

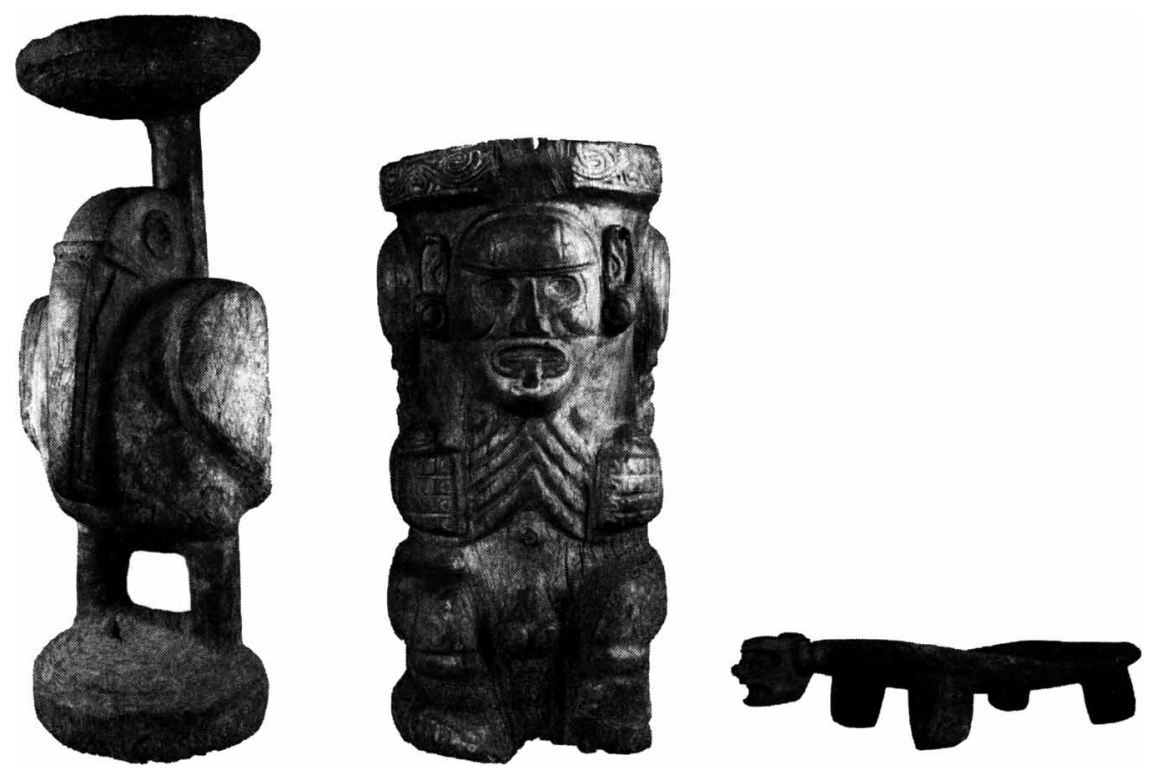

Figure 1 Left to right: a) Pelican cohoba stand, Guaiacum sp., AD 978-1021 (modeled date for outer edge), Aboukir, Jamaica, H: $633 \mathrm{~mm}$; W: $215 \mathrm{~mm}$; D: $205 \mathrm{~mm}$. Courtesy of the National Gallery of Jamaica, Kingston. b) Musée Barrois reliquary, Guaiacum sp., AD 1054-1181 (modeled dates), Dominican Republic/Haiti (?), H: $460 \mathrm{~mm}$; W: $249 \mathrm{~mm}$ (max); D: $250 \mathrm{~mm}$. Courtesy of the Musée Barrois, Bar-le-Duc, France, 850.20.38. c) Robsjohn-Gibbings duho, Guaiacum sp., AD 1451-1517 (modeled dates), L: $412 \mathrm{~mm}$; H: $65 \mathrm{~mm}$ (max); W: $232 \mathrm{~mm}$ (max). Courtesy of the Division of Anthropology, American Museum of Natural History, New York, 25.0/3812.

Taíno sculptures entered Europe with the first shipments of native wealth from the Indies (Las Casas in Parry and Keith 1984:66; Martyr D'Anghera 1970:125), acquired through gift exchanges, trading, or plunder. Over the following centuries, as the Caribbean islands were explored and settled by Old World immigrants, other examples emerged, many found in caves. There are over 300 pieces now held in museums and private collections around the world (Ostapkowicz 1998), and recent work on waterlogged sites such as Los Buchillones, Cuba, and La Aleta, Dominican Republic, has the potential to greatly expand this number (Calvera et al. 1996, 2006; Conrad et al. 2001). Many of the pieces deposited in museums in the 18th and 19th centuries, usually recovered as chance finds or circulating in private collections for decades, if not centuries, have lost their associated information. Hence, little is known about them-for example, how, when, and where they were made, whether their iconography reflects regional and temporal stylistic variations, or what their roles may have been within the context of Taíno culture.

The multidisciplinary Pre-Hispanic Caribbean Sculptural Arts in Wood project was established to provide a chronological framework for a corpus of 66 Taíno sculptures, selected on the basis of their historical significance and wide-ranging provenance. The aims were to build an understanding of the materials used, how they were carved and finished, and the stylistic variations between carvings, the latter potentially based either on their chronological placement or their provenance (with stable isotope studies aiding to confirm their source). Although 7 species of wood were identified as part of the project, Guaiacum spp. overwhelmingly dominated the results, being used for nearly three quarters of the pieces. Two species of Guaiacum, G. sanctum and G. officinale, are of particular interest to this study, with similar growth characteristics and wood structure. Their native range is 
along a western arc in the wider Caribbean, including the Greater Antilles, Bahamas, and the Turks and Caicos Islands, as well as in Central America, from Mexico to Costa Rica, and also Florida.

Dating sculptures such as these, and wood in general, can be problematic for a variety of reasons, including the "old wood effect"- the time between felling and use (in this instance, carving) and the potential for reuse of wood. Slow-growing or long-lived woods could also demonstrate an "inbuilt" age with potentially up to several centuries difference between the pith (the first years of tree growth) and the sapwood, which, as the youngest wood in the original bole, provides a terminus date (i.e. the date of felling). Both G. sanctum and G. officinale are generally considered slow-growing (e.g. Francis 1993; Dertian and Duvall 2009; López-Toledo et al. 2008; López-Toledo 2009; CITES 2011). However, it should be noted that "slow growth" has no precise definition when referring to woods, and such classifications are typically based on individual observation or experience (Wood 2010), details of which are only just beginning to emerge for Guaiacum (López-Toledo et al. 2008; López-Toledo 2009). Prior to this, the perception of Guaiacum's "slow growth" appears to have been influenced - perhaps unduly - by the oft-cited Wilson and Eisner (1968) reference that suggested that some Guaiacum trees in Florida were more than $1000 \mathrm{yr}$ old, although the accuracy of these estimates have since been debated (Tomlinson 1980).

The suitability of dendrochronology for dating tropical woods is still controversial due to the frequent lack of distinct growth rings (e.g. Worbes 2002), although occurrences of tropical trees that do form distinct growth rings on a stable, periodic basis have been recorded, including West Indian pine in the Dominican Republic (Speer et al. 2004) and several species in Bolivian rain forests (Brienen and Zuidema 2005). Guaiacum itself has indistinct or absent growth rings boundaries (Figure 2) (Inside Wood Database 2011). However, regardless of whether or not distinct growth rings are present in the wood used in Taíno sculptures, the application of traditional dendrochronological techniques is clearly not possible, as the pieces cannot be sectioned, polished, etc. as required without causing permanent damage to these unique carvings. Non-invasive techniques such as X-ray CT scans of the growth rings (e.g. Grabner et al. 2009) are only feasible if one can be confident in the growth rates of the species in question, normally not possible with such tropical hardwoods as Guaiacum, which lack distinct growth ring boundaries. For this very reason, there is an absence of reference chronologies for tropical hardwoods in the Greater Antilles, and so any dendrochronological data, even were they available, could not be tied into an established sequence. As recently as 2010 , it has been suggested that radiocarbon dating is still the only accurate method for dating tropical woods without distinct growth rings (Patrut et al. 2010).

Guaiacum wood is extremely hard and heavy, making it very difficult to carve, even with modern steel tools (Ostapkowicz 1998). These characteristics can override some of the concerns for ${ }^{14} \mathrm{C}$ dating discussed above for several reasons: i) the extreme hardness of the seasoned wood makes it likely that pieces were carved while still "green"--or freshly felled—and so easier to work, and this is suggested by the twisting and checking observed in some of the finished pieces (Ostapkowicz et al. 2011); ii) given its natural hardness after drying, the wood was unlikely to have been reused; and iii) to efficiently work the wood, carvers selected the material with an eye to the finished form of the carving, where much of the bole was retained and conservatively reduced to save labor (not only in cutting away extraneous material but also in resharpening stone tools). The other woods under consideration here are Cordia sp. and Carapa sp., neither of which are considered to be as slow growing as Guaiacum, and so do not have the same issues of potentially "inbuilt" age.

The ${ }^{14} \mathrm{C}$ component was of central importance to the Pre-Hispanic Caribbean Sculptural Arts in Wood project (see also Ostapkowicz et al. 2011, 2012), and it is clear from the issues discussed 


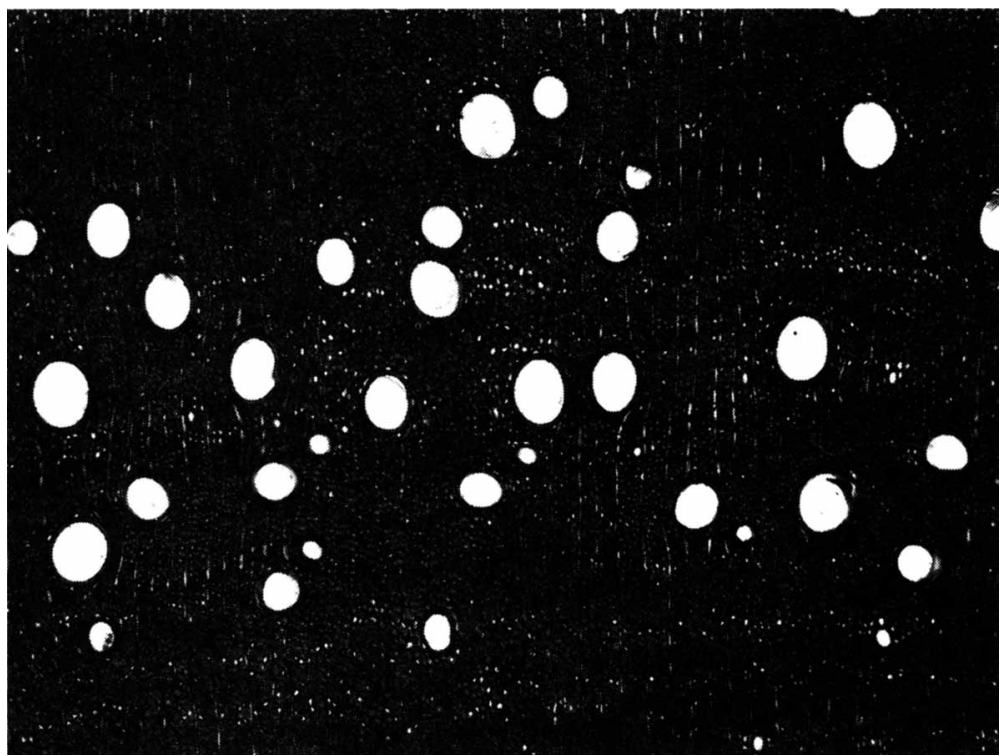

Figure 2 Transverse section of Guaiacum officinale showing a lack of distinct growth rings (image size: $2059 \mu \mathrm{m}$ wide by $1544 \mu \mathrm{m}$ tall). Photo: A Wiedenhoeft.

above that careful sampling was paramount. Our methodology was carefully tailored to the objects under investigation. To establish a reliable chronological framework for the sculptures, it was critical to identify when the selected woods were felled, and likely carved, and hence all pieces dated were sampled at, or close to, the outermost edge, ideally in sapwood where possible, to give a terminus date. As part of our sampling strategy, samples were also taken at the pith (or central heartwood) from 10 of the 11 pieces presented here, to date the first years of growth. Additional dates were measured at specific points within the bole for 3 of the sculptures, and samples were taken from the outer and inner edges of 1 hollow carving. The dates from the 8 pieces carved from Guaiacum were used in the construction of a growth rate model for the species, presented below.

\section{METHODS}

\section{Sampling Strategy}

Samples were collected from 2 or more locations from a total of 11 Taíno sculptures, listed in Table 1. Sampling of the sculptures was often a challenge, requiring sufficient material for a reliable date to be removed from specific locations (namely the pith and outermost rings) without the sampling being too apparent or damaging to the integrity of the objects (many samples were taken in already present cracks or damaged areas to minimize disturbance). Each piece was initially orientated relative to its position within the original bole, and then a small sliver of wood (usually between $30-90 \mathrm{mg}$, but some samples were as small as $6 \mathrm{mg}$ where little material was available) was carefully removed with a scalpel. The MMA cohoba stand was the only piece from which samples were removed using a drill by in-house conservators, as per institutional requirements. Ten artifacts were sampled at the outermost heartwood edge; sapwood in sufficient quantity to sample was present in 1 piece, the Capt. Wheeler duho (Table 1). Ten of the 11 sculptures provided pith dates (Table 1). 


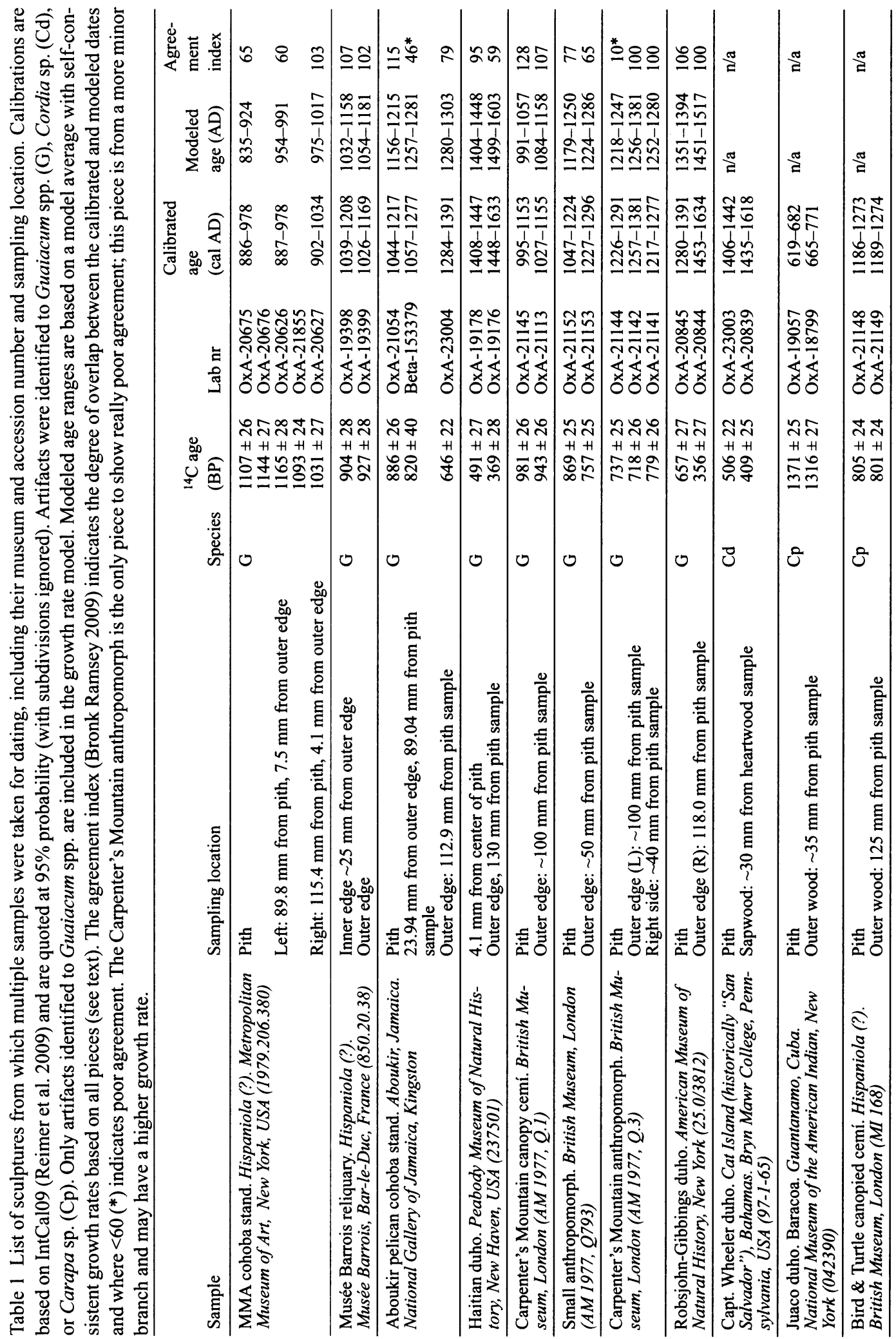


Samples were also taken for dating from selected points within the bole of 3 pieces. The MMA cohoba stand provided a total of 3 samples: 1 from the pith and 2 from within the bole (Figure 3 ). Two aliquots of the pith sample were dated, as part of ORAU's routine quality assurance procedures. The sample from the left of the pith was also pretreated and dated twice, as the initial date was slightly older than expected. An additional sample was taken from approximately midway between the pith and outermost wood samples of the Carpenter's Mountain anthropomorph (Table 1). The Musée Barrois reliquary is hollow (Figure 1b), so a pith sample could not be collected: instead, samples were taken from the outer and inner edges, $\sim 25 \mathrm{~mm}$ apart. Pith and outer edge samples were taken from the Aboukir pelican cohoba stand (Figure la); however, an additional sample $\sim 23 \mathrm{~mm}$ inwards from the outer edge had previously been dated by Beta Analytic (Manuels 2001), and this date was included in the growth rate model. In total, 21 measurements were used in the model.

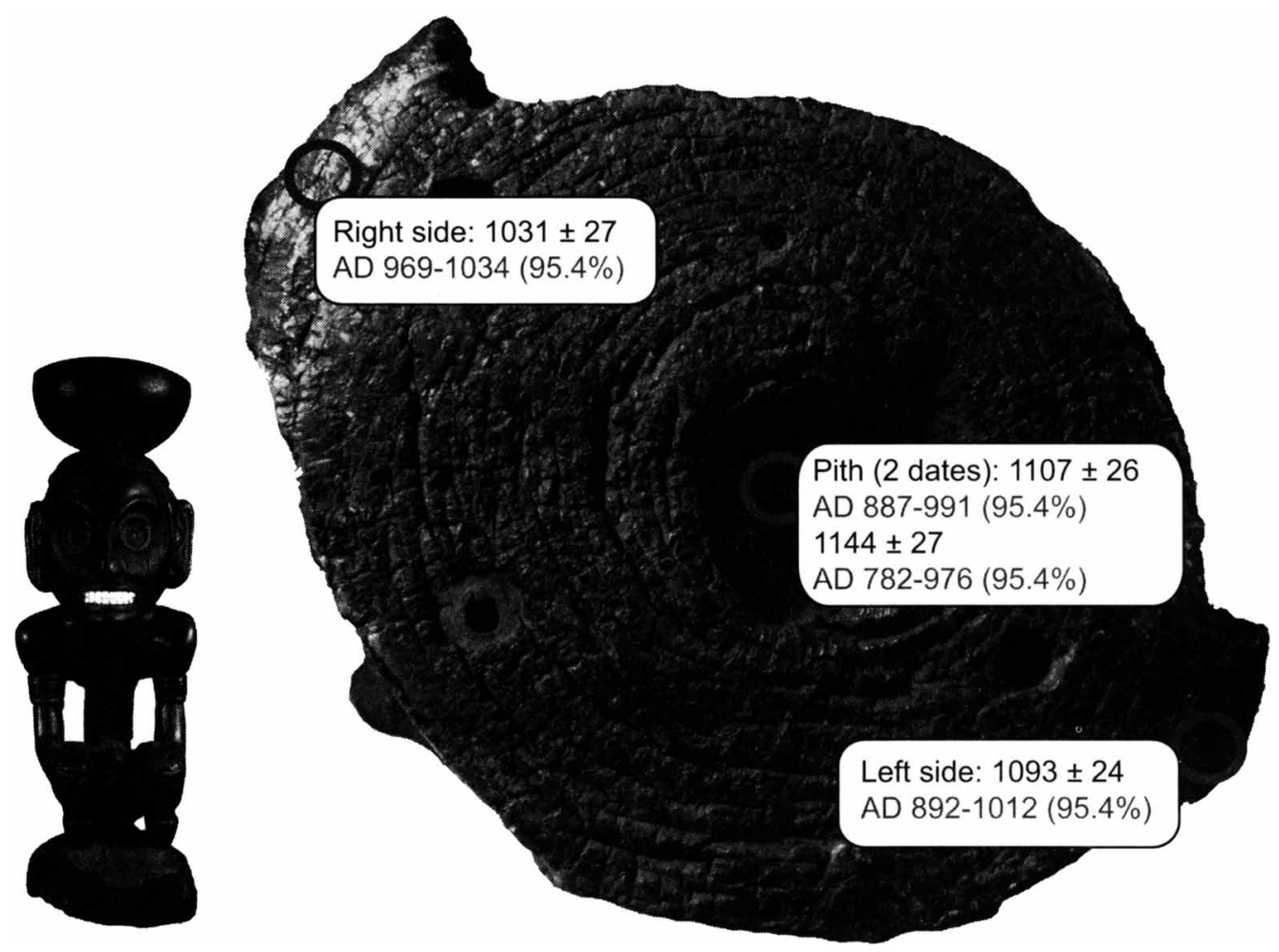

Figure 3 Sampling locations at the base of the MMA cohoba stand and results achieved (NB: the 4 large drill holes and central cavity are all from display mounts). Three ${ }^{14} \mathrm{C}$ samples were taken (circled), but 5 dates were run, as there was sufficient material to duplicate 2 dates. The distance between the pith sampling area and the left sampling site is $89.8 \mathrm{~mm}$ and $7.5 \mathrm{~mm}$ to the outer edge. The measurements for the right side are as follows: within $4.1 \mathrm{~mm}$ of the outer edge, and $115.4 \mathrm{~mm}$ from the pith. [Note that the terms "left" and "right" correspond to the artifact's sides when it is in its normal, upright position, and not to the sampling positions when viewing the base of the sculpture.] Cohoba stand, Guaiacum sp., shell, AD 9751017 (modeled date), Dominican Republic/Haiti(?). H: $665 \mathrm{~mm}$; W: $220 \mathrm{~mm}$ (max); D: $230 \mathrm{~mm}$. The Metropolitan Museum of Art, The Michael C Rockefeller Memorial Collection, Bequest of Nelson A Rockefeller, 1979 (1979.206.380).

\section{Radiocarbon Dating}

Although there are no records that any of the artifacts had been subjected to conservation treatments, this is always a concern with older museum collections, and so all the pieces were initially subjected to a solvent wash comprising of sequential hour-long washes with acetone $\left(45^{\circ} \mathrm{C}\right)$, methanol $\left(45^{\circ} \mathrm{C}\right)$, and chloroform (room temperature) to remove any unknown contaminants and potentially 
also some natural oils and resins from within the wood itself and which may have been mobile across some or all of the bole. The samples were left to air-dry thoroughly before being subjected to a routine acid-base-acid (ABA) treatment consisting of sequential washes with $1 \mathrm{M} \mathrm{HCl}\left(80{ }^{\circ} \mathrm{C}\right.$, $20 \mathrm{~min}), 0.2 \mathrm{M} \mathrm{NaOH}\left(80^{\circ} \mathrm{C}, 20 \mathrm{~min}\right)$, and $1 \mathrm{M} \mathrm{HCl}\left(80^{\circ} \mathrm{C}, 1 \mathrm{hr}\right)$ with thorough rinsing with ultrapure Milli- $\mathrm{Q}^{\mathrm{TM}}$ water after each step. The samples were then bleached with $5 \% \mathrm{w} / \mathrm{v}$ sodium chlorite solution at $\mathrm{pH} 3$ for up to $30 \mathrm{~min}$ at $70^{\circ} \mathrm{C}$ before being washed with water and freeze-dried. They were then combusted to $\mathrm{CO}_{2}$ that was cryogenically distilled and reduced to graphite at $560^{\circ} \mathrm{C}$ in the presence of an iron catalyst, as described by Brock et al. (2010), prior to accelerator mass spectrometry (AMS) dating.

\section{Growth Model}

When dating wood from temperate regions, it is often possible to use tree rings to determine the age difference between different samples taken from the same piece of wood. This improves the precision of the calibrated ages through "wiggle-matching" (Bronk Ramsey et al. 2001). This approach is not possible with tropical woods such as Guaiacum because there are no tree rings as such, and although information on the growth rates of this species is beginning to emerge (López-Toledo et al. 2008; López-Toledo 2009), it is not yet clear how widely applicable these estimates are and whether they can be used to estimate the expected age difference between samples in pieces such as these.

To overcome this limitation, we have combined the information from the 8 Guaiacum carvings for which we have multiple ${ }^{14} \mathrm{C}$ dates (a total of 21 dates). The approach taken is essentially a model averaging approach. We have evaluated the growth rate by building a self-consistent Bayesian model, which assumes that the growth rate of all of the trees from which the pieces are drawn is the same. This is clearly not strictly the case, as the radial growth rate of wood in trees depends on a range of factors, in particular climatic and environmental conditions, and individual trees of the same species can vary in their speed of growth, especially when comparing 2 trees from different geographical locations. Because wood is a water-conducting tissue, conductive area (wood area) must keep pace with the transpirational demands of additional foliage. As trees mature and the diameter increases, the total area of each successive growth ring of a given width increases, and at some point the tree can form a narrower ring (e.g. Zamudio et al. 2002). Thus, tree age (diameter) can be an important determinant of the radial growth rate of wood. However, assuming that the growth rate is the same for all trees from which pieces were taken for this model allows us to find a realistic range of growth rates.

The Bayesian model applied in this case uses a single parameter ( $\mathrm{cm}$-period), which gives the time period for the radial growth of $1 \mathrm{~cm}$ of wood, with a uniform prior, $\mathrm{U}(0,30)$. The distances between samples are defined from measurements made on the pieces, and for the most part are accurate to the nearest $\mathrm{mm}$ - although certain exigencies, such as sampling locations in damaged areas or surrounded by uneven contours resulted in measurements that were taken within 5-mm accuracies. The model is implemented in OxCal (Bronk Ramsey 2009) with code given in the Appendix.

The model assumes linear radial growth independent of age and derives an estimate for the range of possible growth rates consistent with the ${ }^{14} \mathrm{C}$ dates. This range, which is quite broad $(6-13 \mathrm{yr}$ for $1 \mathrm{~cm}$ of growth), is then applied to all pieces and the results of the modeling averaged over this range of possibilities. The model is equivalent to using an a priori assumption of growth rate in this range, but has the benefit that the growth rate is directly determined from the specimens.

It would in principle be possible to generate much more complex models of growth, dependent on the distance of the wood from the pith and taking into account non-linear growth. Such an exercise 
might show that the younger trees usually have faster growth within this range and older trees slower growth. However, all of the pieces come from different parts of the trees and so in any case are likely to see variability in growth rate, something which ${ }^{14} \mathrm{C}$ lacks the resolution to pick up with this kind of data set. In practice, the growth rates in these different circumstances are still likely to remain within the growth rates estimated under the simple model we have applied and, therefore, the results of the modeling should be robust.

\section{RESULTS AND DISCUSSION}

The dates from the 11 pieces sampled are presented in Table 1. The outermost wood dates are all younger than the corresponding pith dates as expected, with the exception of the Musée Barrois reliquary and the Bird and Turtle canopied cemí, where their respective paired dates overlapped. In the case of the reliquary, this is because the samples were taken only $25 \mathrm{~mm}$ apart, suggesting that, at least in this Guaiacum bole, the growth rate was subsumed within the date's margin of error of $\pm 28 \mathrm{yr}$. The Bird and Turtle canopied cemí is carved from Carapa, which is a faster growing species than Guaiacum (Lieberman and Lieberman 1987). The paired dates demonstrate the inbuilt age of the wood in some carvings and the importance of a consistent sampling protocol throughout the project, and provide confidence in both the pretreatment and dating processes, as well as our sampling strategy.

The growth rate model demonstrates that the time required for the growth $1 \mathrm{~cm}$ of Guaiacum wood lies between 6 and 13 yr (see Figure 4a), further refining the 4-14 yr results previously proposed by Ostapkowicz et al. (2011). Although it is recognized that the growth rate of trees can vary due to the age of the tree both physiologically (as younger trees grow faster than older ones) and architecturally (as the diameter of the stem increases, the same amount of added biomass results in narrower rings), the pieces included in the model were likely all carved from different parts of the tree, and hence these factors would have automatically been incorporated into the model. This is supported by the good agreement of our growth rate with the estimates of López-Toledo et al. (2008) that are equivalent to a period of 8-14 yr for smaller trees or 10-13 yr for larger ones (diameter $>60 \mathrm{~cm}$ ). Growth rates of this range are consistent with most of the pieces concerned, except for the Carpenter's Mountain anthropomorph whose dates suggest a faster growth rate, and (only marginally) the Aboukir pelican cohoba stand, where the growth rate would appear to be more variable. It is not surprising that growth rates varied between the different sculptures, as the wood used for each would have been subjected to slightly different environmental and climatic conditions during its growth. However, this estimate seems fairly robust to the inclusion/exclusion of individual pieces; for example, if we exclude the most extreme Carpenter's Mountain anthropomorph date, the growth period for $1 \mathrm{~cm}$ is still estimated to be a similar 6 to $15 \mathrm{yr}$ (see Figure $4 \mathrm{~b}$ ). Using the estimate for the possible growth rates (6$13 \mathrm{yr}$ ) for all pieces, we can then average over all of these possibilities to generate modeled dates for each of the samples, and refine the calibrated ranges for the individual pieces. These are shown in Table 1, along with the OxCal agreement index (Bronk Ramsey 2009) for each of the measurements.

The calibrated ages of the samples from the outermost edges (i.e. those representative of the likely time of carving) of the Taíno pieces presented here (Table 1) range from $\sim \mathrm{AD} 700$ to the time of the first European contact, but generally cluster between AD 900 and 1500, as do the majority of the pieces in the wider study. The "mature" or "classic" period of Taíno art is not considered to begin until about AD 1200, and complex Taíno wooden sculptures are often thought to have been produced within the last few centuries prior to European contact (Rouse 1992:123; Curet 1996:126). These dates show that the Taíno were actually producing elaborate sculptures several centuries earlier than previously thought. However, as the Taíno population expanded and diversified, and different chiefdoms began to emerge from $\sim \mathrm{AD} 600$, it is perhaps not surprising that the caliber of largescale sculpture production also escalated from around the same time. 
a)

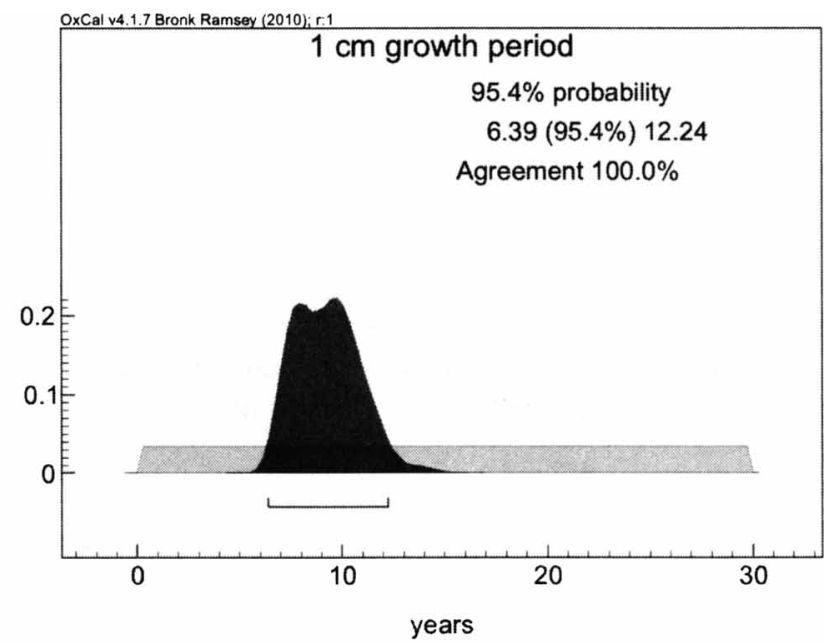

b)

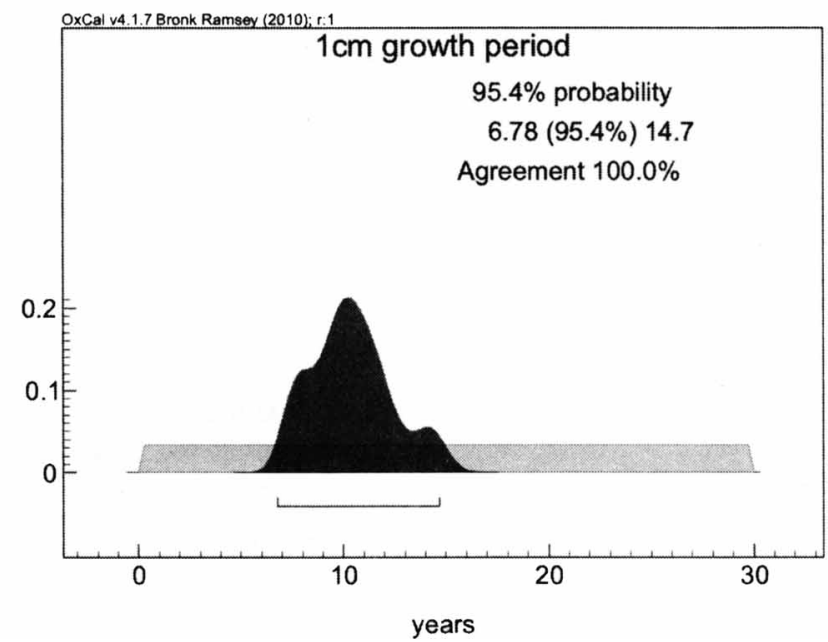

Figure 4 Estimates of the period required for $1 \mathrm{~cm}$ of radial wood growth a) on all pieces, and $b$ ) without the Carpenter's Mountain anthropomorph (which shows poor agreement with the model). The Bayesian model on which these estimates are based assumes a linear radial growth rate, which is consistent between all pieces.

\section{CONCLUSION}

${ }^{14} \mathrm{C}$ dating of wood can be problematic due to the potential reuse of wood and differences in age across a tree from the pith to the sapwood's outer rings. The nature of Taíno wooden sculpturecarved of dense tropical hardwoods that are still poorly known-makes it even more challenging to sample and date. We have demonstrated that dating pairs of samples from the pith and the sapwood or outermost heartwood rings can give confidence in both the sampling and dating procedures implemented. The results can also be used to generate a growth rate model for species that do not have distinct growth rings, and the models can be used to refine the calibrated ages of pieces. With specific regard to Guaiacum, the model has demonstrated that the selected boles used to carve the sculptures grew on average $1 \mathrm{~cm}$ every $6-13 \mathrm{yr}$, and this helps to contextualize and inform on the ${ }^{14} \mathrm{C}$ dates achieved in this study. 


\section{ACKNOWLEDGMENTS}

This work was part of the Pre-Hispanic Caribbean Sculptural Arts in Wood project funded by the British Academy and the Getty Foundation. The authors wish to thank the following museums for permissions to sample: American Museum of Natural History and The Metropolitan Museum of Art (New York, USA); The National Museum of the American Indian (Washington, DC, USA); The Peabody Museum of Natural History (New Haven, USA); Bryn Mawr College (Bryn Mawr, USA); The National Gallery (Kingston, Jamaica); The British Museum (London, UK); and Musée Barrois (Bar-le-Duc, France). All photographs were taken by J Ostapkowicz, unless otherwise stated. B Lorentzen and S Manning are thanked for helpful discussions about dendrochronology of tropical woods. S Harris, T Higham, and R Schulting are also thanked for their contributions.

\section{REFERENCES}

Arrom JJ. 1999. An Account of the Antiquities of the Indians. Durham: Duke University Press.

Brienen RJW, Zuidema PA. 2005. Relating tree growth to rainfall in Bolivian rain forests: a test for six species using tree ring analysis. Oecologia 146(1):1-12.

Brock F, Higham T, Ditchfield P, Bronk Ramsey C. 2010. Current pretreatment methods for AMS radiocarbon dating at the Oxford Radiocarbon Accelerator Unit (ORAU). Radiocarbon 52(1):103-12.

Bronk Ramsey C. 2009. Bayesian analysis of radiocarbon dates. Radiocarbon 51(1):337-60.

Bronk Ramsey C, van der Plicht J, Weninger B. 2001. 'Wiggle matching' radiocarbon dates. Radiocarbon 43(2A):381-9.

Calvera J, Serrano E, Rey M, Pedroso I, Yparraguirre Y. 1996. El sitio arquelógico Los Buchillones. El Caribe Arquelógico 1:59-67.

Calvera J, Rojas V, Cooper RJ. 2006. Los Buchillones: universo de madera. Revista de Ciencias Sociales ACRD:9-16.

CITES [the Convention on International Trade in Endangered Species of Wild Fauna and Flora]. 2011. URL: http://www.cites.org/eng/app/index.php. Accessed 15 July 2011.

Colón F. 1992. The Life of the Admiral Christopher Columbus by His Son Ferdinand. Translated by Benjamin Keen [1959]. New Brunswick: Rutgers University Press.

Conrad GW, Foster JW, Beeker CD. 2001. Organic artifacts from the Manantial de la Aleta, Dominican Republic: preliminary observations and interpretations. Journal of Caribbean Archaeology 2:1-20.

Curet LA. 1996. Ideology, chiefly power, and material culture: an example from the Greater Antilles. Latin American Antiquity 7:114-31.

Dertian JR, Duvall MR. 2009. Biogeography and divergence in Guaiacum sanctum (Zygophyllaceae) revealed in chloroplast DNA: implications for conservation in the Florida Keys. Biotropica 41(1):120-7.

Francis JK. 1993. Guaiacum officinale L. Lignumvitae. Guayacan. Zygophyllacea. Caltrop Family. Washington: USDA Forest Service, International Institute of Tropical Forestry (SO-ITF-SM; 67).
Grabner M, Salaberger D, Okochi T. 2009. The need of high resolution $\mu$-X-ray CT in dendrochronology and in wood identification. In: Proceedings of the 6th International Symposium on Image and Signal Processing and Analysis. New York: Institute of Electrical and Electronics Engineers. p 349-52.

Inside Wood Database. 2011. URL: http://insidewood.lib.ncsu.edu/search. Accessed 13 December 2011.

Lieberman D, Lieberman M. 1987. Forest tree growth and dynamics at La Selva, Costa Rica (1969-82). Journal of Tropical Ecology 3:347-58.

López-Toledo L. 2009. A conservation assessment of endangered tropical tree species: Guiaiacum sanctum and G. coulteri in Mexico [PhD thesis]. University of Aberdeen, UK.

López-Toledo L, Burslem DFRP, Martínez-Ramos M, García-Naranjo A. 2008. Non-detriment findings report on Guaiacum sanctum in Mexico. NDF Workshop case studies; WG1 Trees, Case Study 7.

Manuels M. 2001. Condition and analysis report of four Taíno carvings at the National Gallery of Jamaica. Report on file at National Gallery of Jamaica, Kingston.

Martyr D'Anghera P. 1970. De Orbe Novo: The Eight Decades of Peter Martyr D'Anghera. Translated by Francis August MacNutt. New York: Burt Franklin.

Oliver J. 2009. Caciques and Cemi Idols: The Web Spun by Taino Rulers between Hispaniola and Puerto Rico. Tuscaloosa: University of Alabama Press.

Ostapkowicz J. 1998. Taíno wooden sculpture: rulership and the visual arts in the 12-16th century Caribbean [unpublished PhD thesis]. Centre for the Visual Arts. Norwich: University of East Anglia, UK.

Ostapkowicz J, Wiedenhoeft A, Bronk Ramsey C, Ribechini E, Wilson S, Brock F, Higham T. 2011. "Treasures... of black wood, brilliantly polished': five examples of Taino sculpture from the tenth-sixteenth century Caribbean. Antiquity 85(329):942-59.

Ostapkowicz J, Bronk Ramsey C, Brock F, Higham T, Wiedenhoeft AC, Ribechini E, Lucejko JJ, Wilson S. 2012. Chronologies in wood and resin: AMS ${ }^{14} \mathrm{C}$ dating pre-Hispanic Caribbean wood sculpture. Journal of Archaeological Science 39(7):2238-51. 
de Oviedo y Valdés GF. 1959. Historia General y Natural de las Indias. 2 volumes. Madrid: Biblioteca de Autores Españoles, Ediciones Atlas.

Parry JH, Keith RG, editors. 1984. New iberian World: A Documentary History of the Discovery and Settlement of Latin America to the Early 17th Century. New York: Times Books.

Patrut A, von Reden KF, Lowry DA, Mayne DH, Elder KE, Roberts ML, McNichol AP. 2010. Comparative AMS radiocarbon dating of pretreated versus non-pretreated tropical wood samples. Nuclear Instruments and Methods in Physics Research B 268(7-8):910-3.

Reimer PJ, Baillie MGL, Bard E, Bayliss A, Beck JW, Blackwell PG, Bronk Ramsey C, Buck CE, Burr GS, Edwards RL, Friedrich M, Grootes PM, Guilderson TP, Hajdas I, Heaton TJ, Hogg AG, Hughen KA, Kaiser KF, Kromer B, McCormac FG, Manning SW, Reimer RW, Richards DA, Southon JR, Talamo S, Turney CSM, van der Plicht J, Weyhenmeyer CE. 2009. IntCal09 and Marine09 radiocarbon age calibration curves, 0-50,000 years cal BP. Radiocarbon 51(4): $1111-50$.

Rouse I. 1992. The Tainos: Rise and Decline of the People Who Greeted Columbus. New Haven: Yale Uni- versity Press.

Speer JH, Orvis KH, Grissino-Mayer HD, Kennedy LM, Horn SP. 2004. Assessing the dendrochronological potential of Pinus occidentalis Swartz in the Cordillera Central of the Dominican Republic. The Holocene 14(4):563-9.

Tomlinson PB. 1980. The Biology of Trees Native to Tropical Florida. Allston: Harvard University Publishing.

Wilson EO, Eisner T. 1968. Lignumvitae - Relict Island. Natural History 77:52-7.

Wilson S. 2007. The Archaeology of the Caribbean. Cambridge: Cambridge University Press.

Wood K. 2010. Growth Rates of Common Tress Species in Westminster, Colorado. Colorado State Forest Service, USA.

Worbes M. 2002. One hundred years of tree-ring research in the topics - a brief history and an outlook to future challenges. Dendrochronologia 20:217-31.

Zamudio F, Baettyg R, Vergara A, Guerra F, Rozenberg P. 2002. Genetic trends in wood density and radial growth with cambial age in a radiata pine progeny test. Annals of Forest Science 59(5-6):541-9.

\section{APPENDIX - OXCaI MODEL CODE}

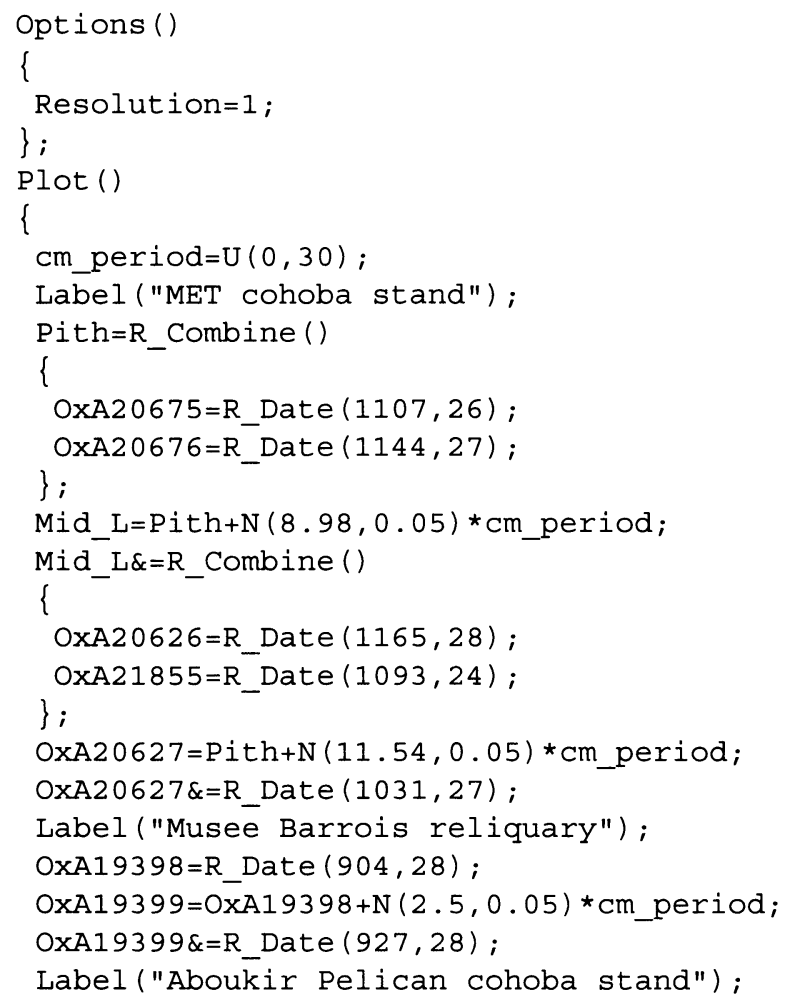




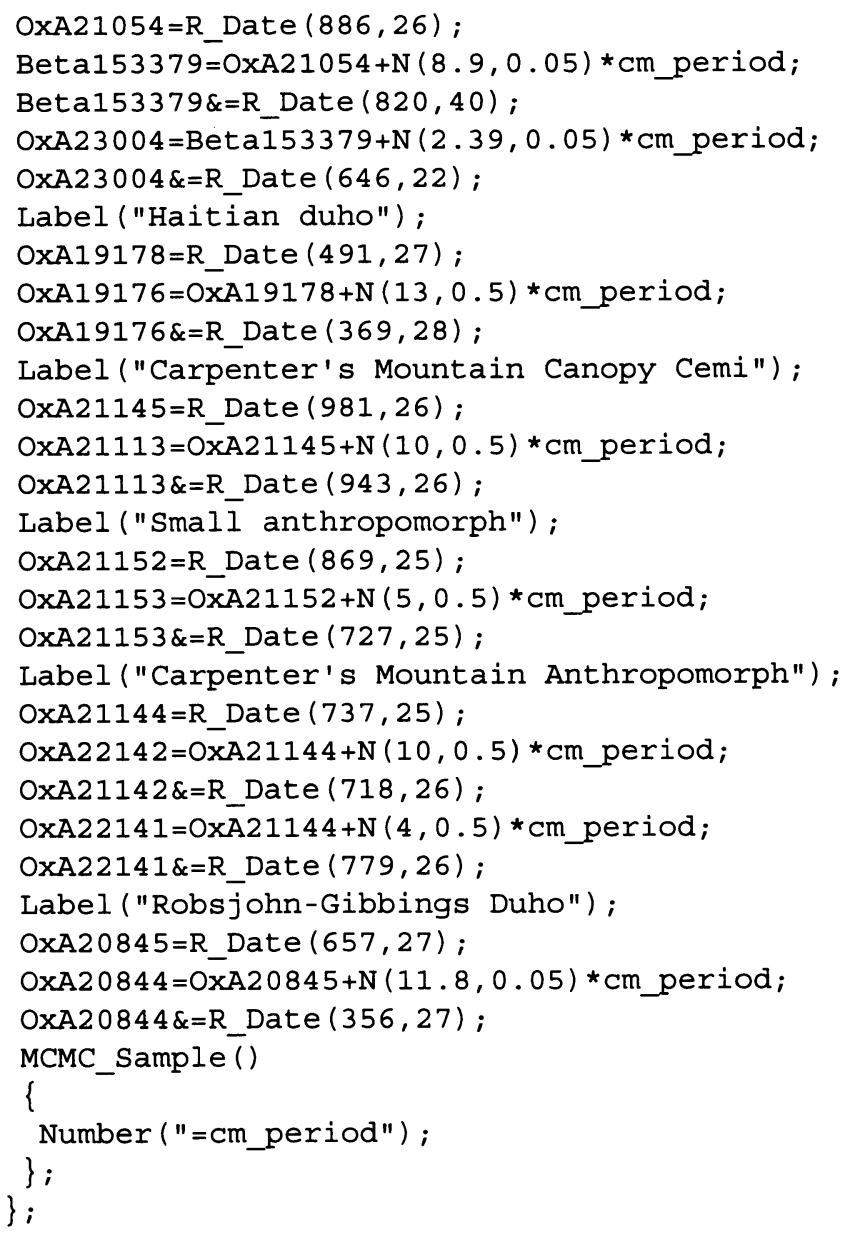

